\title{
"Do We Really Need Hepatitis B on the Second Day of Life?" Vaccination Mandates and Shifting Representations of Hepatitis B
}

\author{
Elena Conis
}

Published online: 12 January 2011

C The Author(s) 2011. This article is published with open access at Springerlink.com

\begin{abstract}
In the decade following hepatitis B vaccine's 1981 approval, U.S. health officials issued evolving guidelines on who should receive the vaccine: first, gay men, injection drug users, and healthcare workers; later, hepatitis B-positive women's children; and later still, all newborns. States laws that mandated the vaccine for all children were quietly accepted in the 1990s; in the 2000s, however, popular anti-vaccine sentiment targeted the shot as an emblem of immunization policy excesses. Shifting attitudes toward the vaccine in this period were informed by hepatitis B's changing popular image, legible in textual and visual representations of the infection from the 1980s through the 1990s. Notably, the outbreak of AIDS, the advent of genetically engineered pharmaceuticals, and a Democratic push for health reform shaped and reshaped hepatitis B's public image. Hepatitis B thus became, in turn, an AIDS-like scourge; proof of a new era of pharmaceuticals; a threat from which all American children had a right to be protected; and a cancer-causing infection spread by teenage lifestyles. The metamorphosis of the infection's image was reflected in evolving policy recommendations regarding who should receive the vaccine in the 1980s, and was key to securing broad uptake of the vaccine in the 1990s.
\end{abstract}

Keywords Hepatitis B · Vaccines · Vaccination · Representations · Imagery $\cdot$ HIV $\cdot$ Health policy

\section{Introduction}

Today, most newborns in the United States are vaccinated against the hepatitis B virus, usually in the first few days of life. ${ }^{1}$ The practice of vaccinating infants against hepatitis B, a blood-borne virus that attacks the liver, is a popular target for contemporary vaccine

\footnotetext{
${ }^{1}$ Centers for Disease Control. "Newborn Hepatitis B Vaccination Coverage among Children Born January 2003-June 2005, United States," Morbidity and Mortality Weekly Report 57; 30 (2008), 825-828.

E. Conis $(\triangle)$

History of Health Sciences, University of California, San Francisco, San Francisco, CA, USA

e-mail: econis@emory.edu

E. Conis

Rollins School of Public Health, Emory University, Atlanta, GA, USA
} 
critics, who for the last decade have argued that the virus is a sexually-transmitted infection that poses little or no risk to babies. Indeed, this is how federal health officials themselves characterized the virus back in 1981 when they first approved the vaccine. However, by 2000, 47 states had mandated the vaccine for all schoolchildren with little or no resistance from parents. The widespread adoption of hepatitis B vaccine mandates in the 1990s thus raises the question: how did a vaccine with such a limited initial target population come to be accepted as compulsory for every child in the country?

The answer lies in an examination of gradual adjustments to the image of hepatitis B infection, an image created and recreated by ever-shifting verbal descriptions, media portrayals, and textual descriptions of the disease in the two decades following the vaccine's introduction. Prior to the approval of the hepatitis B vaccine by the U.S. Food and Drug Administration (FDA), the virus was rarely the object of media attention and was only faintly visible to the American public. But as scientific discoveries leading to the vaccine accumulated, hepatitis B acquired an increasingly public image. Initially, in the late 1970s and early 1980s, the image of hepatitis B constructed by popular portrayals was that of a deadly but foreign infection, a scientific obscurity of little direct relevance to most Americans. Shifting cultural, scientific, and political preoccupations, however, acted to reshape continually this (not strictly visual) image, as evidenced in media and scientific reports on hepatitis B and the policies that made it mandatory for children in the 1980s and 1990s. In particular, the outbreak of AIDS in the early 1980s, the advent of geneticallyengineered pharmaceuticals in the late 1980s, and the political push for health reform in the early 1990s all left an indelible imprint on the picture of hepatitis B being held up before Americans. Through these constantly shifting portrayals, hepatitis B became, in turn, a sexually transmitted AIDS-like scourge; an example of the promise of a new era of pharmaceuticals; a threat from which all American children had a right to be protected; and a cancer-causing infection spread by teenage lifestyles. Examination of these shifting representations of hepatitis B reveals the process by which the virus was framed as a widespread infection worth preventing by the universal vaccination of children. In the case of hepatitis B, the metamorphosis of the infection's image was reflected in constantly revolving policy recommendations regarding who should receive the vaccine in the 1980 s, and was ultimately key to securing broad uptake of the infection's vaccine in the 1990s.

\section{"A disease affecting health workers, male homosexuals and drug addicts"}

Like many twentieth-century pharmaceutical discoveries, the development of the hepatitis B vaccine was, in part, a matter of happenstance. In 1963, research physician, Baruch Blumberg, was investigating variations in susceptibility to infections among different ethnic and racial groups when he identified a protein in the blood of Australian aborigines, which he dubbed the Australia antigen. Blumberg and colleagues initially surmised that the protein was inherited, but they soon noted a correlation between Australia antigen in the blood and hepatitis B infection, then called serum hepatitis. Gradually, the researchers came to suspect that Australia antigen, which floated freely in the blood of people infected with hepatitis B, was part of the virus that caused hepatitis. In 1967, they determined that Australia antigen was, in fact, a surface protein on the virus that caused the disease; the discovery quickly led to a test to screen blood and diagnose patients. In related research, Blumberg and colleagues found that monkeys injected with highly purified Australia antigen (later renamed hepatitis B surface antigen or HBsAg) did not progress to serum hepatitis; the discovery suggested that non-infectious material could be separated from the virus itself. In 1969, the researchers 
patented the process for separating and purifying the antigen. The basis for the development of a vaccine, what Blumberg called "the most significant outcome" of their work, had thus been discovered. ${ }^{2}$

Over the course of the 1970s, the diagnostic test that Blumberg's research group had developed revealed the full extent of the hepatitis B epidemic, both in the U.S. and around the world. Two distinct forms of hepatitis, A and B (formerly infectious and serum hepatitis, respectively) had been known since the 1950s, but countless cases of the latter had gone undetected, in large part because of the vague symptomatic presentation of hepatitis B infection. Infection may or may not cause acute symptoms, including debilitating fatigue, nausea, and loss of appetite, and acute symptoms may or may not be fatal. Those who do recover may or may not become chronic carriers. Carriers, in turn, may or may not become victims, decades later, of hepatitis-induced cirrhosis or liver cancer. ${ }^{3}$ Furthermore, hepatitis B's fairly mundane acute symptoms meant that, for decades, it was routinely confused with other conditions. In the 1970s, however, armed with the newly developed diagnostic protocols, researchers identified for the first time more than 200,000 new cases in the U.S. each year, and more than 200 million carriers worldwide. Concurrent epidemiological studies also identified those at highest risk of the disease; in addition to health care workers, the list included hemophiliacs, prisoners, gay men, injection drug users, sex workers, native Alaskans, and immigrants from sub-Saharan Africa, China, and southeast Asia. ${ }^{4}$

As development of a vaccine against the infection accelerated in the late 1970s, Blumberg and other infectious disease experts predicted that effective vaccine would save hundreds of thousands, if not millions, of lives. ${ }^{5}$ But news of the potential vaccine, and of hepatitis B itself, rarely reached lay audiences over the course of the 1970s. The disease did have isolated moments in the spotlight: in 1974, Dr. Norman Pastorek, host of the television show Today's Health, developed acute hepatitis B when a surgical patient's blood splashed in his eye; he chronicled in detail the disease's "mean, sneaky malevolence" on air and in print. ${ }^{6}$ Two years later, hepatitis B made headlines again when Blumberg shared the Nobel Prize in Medicine for his work on the disease. ${ }^{7}$ The press also reported on the 1979 outbreak of hepatitis B among youth who shared needles to inject the recreational drug methylene deoxyamphetamine. ${ }^{8}$ Such stories began to illustrate the picture emerging from epidemiological studies for the public: that the disease posed a risk to specific subsets of the population including surgeons and drug users. However, the image sketched by such stories was faint, as for most of the 1970s, the public heard—and likely understood — very little about hepatitis B.

On the eve of the hepatitis B vaccine's introduction, lay Americans therefore had little reason to view the disease as a direct threat to their health. Early press reports on the vaccine continually reaffirmed this notion. In 1980, the CBS evening news reported that while hepatitis B struck developing countries in Asia and Africa in "epidemic proportions," in the U.S., it affected mainly "patients on dialysis, medical personnel, and people living in institutions." News anchor, Dan Rather, echoed this when he reported on the hepatitis B

\footnotetext{
${ }^{2}$ B.S. Blumberg, Hepatitis B: The Hunt for a Killer Virus (Princeton: Princeton University Press, 2002).

3 Ibid.

${ }^{4}$ W. Muraskin, "Hepatitis B as a Model (and Anti-Model) for AIDS," in AIDS and Contemporary History, eds. V. Berridge and P. Strong (Cambridge: Cambridge University Press, 1993), 108-132.

${ }^{5}$ Blumberg, 134-136.

${ }^{6}$ N. Pastorek, "Hepatitis," Today's Health, September 1974, 46+.

7 B. Rensberger, "Sketches of Two Winners of Nobel Prizes in Medicine," New York Times, 15 October 1976, 13 .

8 Anonymous, “A Wave of Death from Hepatitis," Newsweek, 27 August 1979, 72.

${ }^{9}$ CBS Evening News, September 29, 1980, (Vanderbilt Television News Archive).
} 
vaccine's approval in 1981, stating that a vaccine had been approved for "a disease affecting health workers, male homosexuals, and drug addicts. $" 10$ On NBC, the evening news anchor described hepatitis B to the public as follows: "Hospital workers get it, so do drug addicts, mental patients, homosexuals, and millions of people in Africa and Asia." The network's subsequent segment on the vaccine focused largely on the "medical adventure story" of the virus's discovery, which a reporter recounted over grainy images of Aborigines in native attire. ${ }^{11}$

Historian William Muraskin has argued that representation of hepatitis B was deliberately constructed by a medical profession acting in self-interest. Having been identified as a high-risk group themselves, health care workers, in Muraskin's analysis, endeavored to define hepatitis B infection as an issue "private" to their profession and outside the public's purview. The media, reliant on the medical community for information about the virus, reported what they were told: that gays, injection drug users, and certain immigrants and refugees were at high risk and that the spread of hepatitis in iatrogenic settings was controlled through the use of gowns, masks, gloves, and other hygienic practices. The health care profession's internal policy-of voluntary testing for carrier status-became the implicit policy toward the population at large, as well. The resulting public ignorance, Muraskin concludes, was two sided: it prevented "hysteria and discrimination of carriers," but it also hampered public awareness of the extent of the epidemic and the true risk of infection. ${ }^{12}$ Muraskin's assessment assumes that the risk of infection was widespread at this time; regardless of whether this was the case, what is clear is that in the period prior to the approval of the hepatitis B vaccine, the popular impression of the virus as posing little threat to "average Americans" had been deeply forged.

\section{Two novel vaccines}

The hepatitis B vaccine approved by the FDA in 1981 was an unusual product in the history of viral vaccine development. Instead of containing live, weakened virus or killed, denatured virus, Heptavax B, as it was called, contained purified antibodies harvested from the blood of people infected with the virus. In a display of awe and enthusiasm for scientific discovery, the same news reporters who had downplayed the disease's risk for average Americans played up, in the next breath, the new vaccine's novel form. Dan Rather reported that the vaccine was the "first completely new viral vaccine in 10 years," and the "first vaccine ever licensed in the United States that is made directly from human blood."13 When clinical trials revealed that the vaccine was over $92 \%$ protective, Newsweek called its blood-derived antibodies "ingenious," and magazines from Time to Glamour called the vaccine a "medical breakthrough." 14 Fervent reports in popular and scientific journals proclaimed that hepatitis B-still a little-known disease to the American public — would

\footnotetext{
${ }^{10}$ CBS Evening News, November 16, 1981, (Vanderbilt Television News Archive).

${ }^{11}$ NBC Nightly News, November 16, 1981, (Vanderbilt Television News Archive).

${ }^{12}$ W. Muraskin, "The Silent Epidemic: The Social, Ethical, and Medical Problems Surrounding the Fight against Hepatitis B,” Journal of Social History 22 (1988): 277-298.

${ }^{13}$ CBS Evening News, November 16, 1981.

14 J. Seligman, “A Vaccine for Hepatitis," Newsweek, 13 October 1980, 132; Anonymous, "Hepatitis Hope," Time, 13 October 1980; C. Sherman, "Hepatitis: Why It's So Common,” Glamour, March 1981, 268.
} 
soon join such well-known pathogenic villains as smallpox and polio as a problem of the past. $^{15}$

Such rhetoric was quickly dampened by another discovery, however. The clinical trials that had tested the vaccine in the 1970s had included only gay men who had been identified as being at high risk of the infection. When, in 1982, the federal Advisory Committee on Immunization Practices (ACIP) issued its customary recommendations on who should receive the vaccine, the list included those considered to be at highest risk for the disease, including gay men, injection drug users, sex workers, health care workers with blood contact, and select immigrants. But the FDA's approval of the plasma-derived vaccine had closely coincided with reports of a deadly new disease among gay men. Within a year, health officials had documented a high rate of hepatitis B infection not only among gay men but also among gay men who were sufferers of AIDS. The announcement spurred fears that the new vaccine was contaminated with AIDS. ${ }^{16}$ In 1982 and 1983, newspapers reported that gay men and injection drug users were frequent blood donors for the vaccine and that many health care workers had refused the vaccine for this very reason. ${ }^{17}$

Restrictions on blood donation - and a lack of evidence linking AIDS cases to the new vaccine - appeared to quell such fears. ${ }^{18}$ But the emergence of AIDS had a profound and lasting impact on the nature of media representations of hepatitis B. No sooner did the potential link between hepatitis B vaccination and HIV infection fade from media reports than a new link between the two viruses emerged; this new link, a recitation of the similarities between the two infections, would persist in popular and scientific discourse for well over a decade. The analogy between AIDS and hepatitis B infection had been drawn early on by epidemiologists working to discover the causative agent of AIDS. Both diseases, scientists noted, appeared to be transmitted sexually, showing a pattern of infection among injection drug users and blood transfusion recipients. When the Centers for Disease Control (CDC) identified the groups at "high-risk" for AIDS in 1983-gay men with multiple sex partners, I.V. drug users, Haitian immigrants and hemophiliacs - these closely mirrored the list earlier reported to be at high risk of hepatitis B. ${ }^{19}$ Such parallels were repeatedly echoed by the media. As a 1985 cover story on AIDS in Time pointed out, both diseases were scourges of "drug addicts, blood recipients and gay men," and researchers were uncertain as to whether hepatitis B was a "co-agent of AIDS or merely [a] tagalong infection."20

Media coverage also pointed out not only how hepatitis B was similar to AIDS but also how it was worse: 15 times more common, 200 times more infectious, far more stable in the environment, responsible for far more deaths, and, unlike HIV, spread by casual

\footnotetext{
${ }^{15}$ See Seligman, 132 and L. Altman, "Tests of Hepatitis B Vaccine Show Nearly Complete Rate of Protection," New York Times, 29 September 1980, A1.

${ }^{16}$ D. Dickson, “AIDS Fears Spark Row over Vaccine," Science, 221 (1983): 437.

${ }^{17}$ On health care workers refusing vaccine, see UPI, "Two Doctors in U.S. Agency Back Hepatitis B Vaccine," New York Times, 11 February 1983, A14.

${ }^{18}$ See for example C. Russell, "U.S. Issues New Policy on Transfusions to Avoid AIDS Disease," Washington Post, 4 March 1983, A3; Centers for Disease Control, "Hepatitis B Vaccine: Evidence Confirming Lack of AIDS Transmission," Morbidity and Mortality Weekly Report 33 (1984): 685.

${ }^{19}$ This pattern has been noted by G. Oppenheimer, "In the Eye of the Storm: The Epidemiological Construction of AIDS," in AIDS: The Burdens of History, eds. E. Fee and D. Fox (Berkeley: University of California Press, 1988), 267. For an example, see Centers for Disease Control, "Recommendation of the Immunization Practices Advisory Committee (ACIP) Inactivated Hepatitis B Virus Vaccine," Morbidity and Mortality Weekly Report 31; 24 (1982), 317-322.

${ }^{20}$ C. Wallis, "AIDS: A Growing Threat," Time, 12 August 1985.
} 
contact. $^{21}$ But the public could take solace, the vice chair of the National Foundation for Infectious Diseases pointed out in a letter to the New York Times, in the fact that a vaccine existed to keep this "cousin of AIDS" at bay. ${ }^{22}$ This message, that the hepatitis B vaccine was a beacon of hope in a time of fear, was repeated often in the press. There's no cure for AIDS, Gay Community News told readers, but there is one for hepatitis B, which kills five times as many people each year. ${ }^{23}$ Mademoiselle issued the same message: "There is no AIDS vaccine yet, but there are two new ones against hepatitis B."24

That second hepatitis B vaccine, widely available by the late 1980 s, was a vastly different product from the first, blood-derived vaccine. Recombivax HB, the geneticallyengineered hepatitis B vaccine approved in 1986, contained viral proteins not harvested from diseased patients in the clinical setting but rather manufactured by recombinant yeast in the lab. Before it was licensed, press reports hailed Recombivax B for its potential to prove that genetic engineering would revolutionize the pharmaceutical industry. Scientists and the reporters who quoted them called biotech vaccines "exciting and imaginative," and referred to the hepatitis B vaccine specifically as a "pioneering product." 25 Researchers told the New York Times that biotech shots were "cutting edge weapons" that would eliminate not only hepatitis B but also AIDS and malaria. ${ }^{26}$ The business press breathlessly reported on the race between "tiny" California biotech firms to produce the world's first geneticallyengineered vaccine, and when Chiron's Recombivax was approved, Venture magazine crowned it one of the best entrepreneurial ideas of $1986 .{ }^{27}$ The approval of Recombivax $\mathrm{HB}$ - the first genetically-engineered vaccine and the fifth genetically-engineered pharmaceutical to make it to market-was heralded on the front pages of the New York Times, the Los Angeles Times, the Wall Street Journal and elsewhere for ushering in what FDA commissioner, Frank Young, called a "new era in vaccine production."28

That era was long awaited. In the 1960s, lawsuits over polio vaccine tainted with live virus had prompted half the nation's vaccine manufacturers to pull out of the market altogether - a fact the business press repeated as they reported on the new vaccine. ${ }^{29}$ The genetically-engineered hepatitis B vaccine was enthusiastically received by investors, the pharmaceutical industry, and health professionals not only because it held the promise of a new generation of vaccines (and thus new markets), but also for its potential to address safety concerns that had damaged the industry and shaken consumer confidence. In the words of the Wall Street Journal's editorial board, Chiron's discovery brought an end to the days when vaccine development was "an inexact scientific art." 30 "We see no reason why our approach won't work with virtually any infectious disease, whether it is viral, bacterial

\footnotetext{
${ }^{21}$ C. Sacra, "A Vaccine for Lovers," Health 21 (1989): 47.

22 S. Kuvin, "Vaccination Can Halt Epidemic of Hepatitis B, Cousin of AIDS," New York Times, 9 April 1989, E24.

23 Anonymous, "Hepatitis, Health, and the Hard Sell," Gay Community News, 10 September 1983.

${ }^{24}$ N. Geary, "Health News: Hepatitis B," Mademoiselle, April 1993, 120.

${ }^{25}$ See for example, C. Wallis, "Made-to-Order Vaccines," Time, 31 October 1983; and J. Castro, "A Breakthrough for Biotech," Time, 4 August 1986.

${ }^{26}$ H. Schmeck, "The New Age of Vaccines," New York Times Magazine, 29 April 1984, 58+.

27 See for example J. Packer, "Chiron Nears Sale of New Hepatitis Vaccine," San Jose Business Journal 3; 41 (1986): 3; and T. Post, D. Eberwine, D.G. Winder and E.M. Ebler, "The Year's Best Entrepreneurial Ideas," Venture 8; 12 (1986): 28.

${ }^{28}$ P. Boffey, "U.S. Approves a Genetically Altered Vaccine," New York Times, 24 July 1986, A1; M. Cimons, "First Human Vaccine Produced by Genetic Engineering OK'd by FDA," Los Angeles Times, 24 July 1986, 1; and J. Davidson, "Lab-Made Vaccine for Hepatitis B Is Cleared by FDA," Wall Street Journal, 24 July 1986, 1.

${ }^{29}$ G. Geipel, "A Shot in the Arm for Vaccine Makers,” Business Week, 4 August 1986, 29.

${ }^{30}$ Editorial, "Science and Demagoguery," Wall Street Journal, 31 July 1986, 1.
} 
or even parasitic in nature," one researcher told Time. ${ }^{31}$ Nodding implicitly toward past and present fears, another researcher told the magazine that genetically-engineered vaccines eliminated the "risk of actually getting herpes, hepatitis B or influenza from the injection, since the viruses themselves are not present in the formula." 32 Because the new vaccine did not contain a whole virus, it "just can't do any damage, period," promised FDA microbiologist Richard Daemer. ${ }^{33}$ These sentiments were echoed by FDA Commissioner Young in a press statement he made on the occasion of Recombivax's approval. "These techniques should be...extended to any virus or parasite," he stated. He went on to say that while the plasma-derived vaccine had never posed a risk of AIDS, the new "lab-made vaccine" should further reassure people. He also strongly urged those at high risk of hepatitis B to take advantage of this "new life-saving protection." 34

\section{A push for widespread vaccination}

Young's plea came as public health officials were bemoaning stubbornly low hepatitis B vaccination rates. In the 5 years since the ACIP had recommended that gay men, injection drug users, health care workers, and select immigrants be vaccinated against the infection, hepatitis B prevalence had not decreased but rather increased, with rates particularly high among young adults. ${ }^{35}$ Incrementally, federal recommendations evolved in response. In 1988, the ACIP recommended that all pregnant women be tested for hepatitis B, and, if positive, their infants vaccinated within $12 \mathrm{~h}$ of birth to prevent transmission to the next generation. ${ }^{36}$ When disease incidence persisted at high rates, the ACIP altered its strategy again, recommending universal infant vaccination against hepatitis B in $1991 .^{37}$ Health officials acknowledged that the new strategy was necessary "because vaccinating persons engaged in high-risk behaviors, life-styles or occupations...has not been feasible" and because many infected people had "no identifiable source for their infections." 38

The message that just about everyone was at risk of hepatitis B came to dominate media reports on the disease by the early 1990s. Outlets from the Philadelphia Tribune to Good Housekeeping reported that a third of people with the disease were not in any of the known risk groups. ${ }^{39}$ Redbook warned readers that hepatitis was "spreading fast," and the Boston Globe noted that hepatitis was spread by sharing gum, food, toothbrushes, and razors and by body piercing. ${ }^{40}$ New York magazine, in a feature titled, "The Other Plague," recounted

\footnotetext{
${ }^{31}$ Wallis, "Made-to-Order Vaccines."

32 Ibid.

33 D. Stehlin, "Hepatitis B: Available Vaccine Safe and Underused," FDA Consumer Magazine, May 1990.

${ }^{34}$ Associated Press, "FDA Approves Gene-Engineered Hepatitis Vaccine," Dallas Morning News, 24 July 1986, 5A.

35 Centers for Disease Control. "Surveillance Summary Viral Hepatitis_-1984," Morbidity and Mortality Weekly Report 36; 3 (1987), 42-43.

${ }^{36}$ Centers for Disease Control. "Recommendations of the Immunization Practices Advisory CommitteePrevention of Perinatal Transmission of Hepatitis B Virus: Prenatal Screening of All Pregnant Women for Hepatitis B Surface Antigen,” Morbidity and Mortality Weekly Report 37; 22 (1988), 341-346, 351.

37 Centers for Disease Control. "Hepatitis B Virus: A Comprehensive Strategy for Eliminating Transmission in the United States through Universal Childhood Vaccination: Recommendations of the Immunization Practices Advisory Committee (ACIP)," Morbidity and Mortality Weekly Report 40; RR-13 (1991), 1-19. 38 Ibid.

39 Anonymous, "Hepatitis B 200x More Contagious Than AIDS," Philadelphia Tribune, 31 December 1991, 4B; L. Holland, "The ABC's of Hepatitis," Good Housekeeping, April 1991, 239.

${ }^{40}$ L. Laurence, "Beware the Quiet Killer," Redbook, October 1991, 24; S. Coleman, "Q\&A with Leslie Hsu," Boston Globe, 15 February 1998, 2.
} 
the stories of a young woman who contracted a fatal case by getting her ears pierced, a young man who was infected when mugged at knife-point, and a woman infected at a nail salon. ${ }^{41}$ Frequent mention of the prevalence of asymptomatic carriers heightened the sense of an immediate health threat: in the words of the New York magazine reporter, anyone could be one of the U.S.'s 1.5 million "Typhoid Marys," unwittingly transmitting hepatitis $\mathrm{B}$ to people unaware of their risk. ${ }^{42}$

Meanwhile, health officials at the CDC were considering not just revised recommendations to increase hepatitis $\mathrm{B}$ vaccination but a broader program to encourage higher vaccination rates overall. The worst measles epidemic in over a decade had swept the nation in 1989 and 1990, infecting more than 50,000 people and causing hundreds of deaths. ${ }^{43}$ Rates of rubella and pertussis were also on the rise. When a federal vaccine advisory panel (a panel distinct from the ACIP) studied the measles outbreaks, their resulting White Paper concluded that the epidemic was driven by low immunization rates among pre-school-aged children. ${ }^{44}$ (Immunization of schoolchildren, by contrast, had reached a peak in the early 1980s following a national immunization campaign sponsored by Jimmy Carter's administration.) Low immunization rates among the very young, the panel argued, were the result of costly vaccines, inadequate insurance policies, and other barriers to health care. The nation's failure to immunize all susceptible children was, in their assessment, the result of a broken health care system, an issue that had become a top concern for most Americans on the eve of the 1992 presidential election.

In that race, presidential candidate Bill Clinton had campaigned — and was elected — on a platform that emphasized the need to fix the nation's ailing health care system. ${ }^{45}$ His first month in office, he proposed a measure that amounted to health reform in miniature, a billion dollar "universal purchase" program, in which the federal government would become the sole buyer of all vaccines and distribute them free of cost to all children, regardless of family income. ${ }^{46}$ As Congress debated the proposal, Clinton spent the spring of 1993 championing the cause of childhood immunization. His administration spread the message that vaccines were a child's basic right, one being violated by greedy drug companies. "Our message to the drug companies today is...you're not going to profit at the expense of our children," Clinton said at one press conference. ${ }^{47}$ The head of the National Vaccine Program Office told the New York Times that immunization had become "a privilege," with the implication that it was the right of all children to be vaccinated. ${ }^{48}$ Secretary of Health and Human Services, Donna Shalala, expounded on this line of

${ }^{41}$ J.H. Tanne, "The Other Plague: Potentially Deadly Hepatitis Is Fifteen Times More Common Than AIDS," New York, 11 July 1988, 34.

42 Ibid, 35.

${ }^{43}$ Centers for Disease Control. "Current Trends Measles_-United States 1990," Morbidity and Mortality Weekly Report 40; 22 (1991), 369-372.

${ }^{44}$ National Vaccine Advisory Committee, "The Measles Epidemic: The Problems, Barriers, and Recommendations " JAMA 266; 11 (1991): 1547-1552; see also P. Hilts, "Panel Ties Measles Epidemic to Breakdown in Health System," New York Times, 9 January 1991, A17.

${ }^{45}$ For an analysis of the Clinton health reform effort, see T. Skocpol, Boomerang: Clinton's Health Security Effort and the Turn against Government in U.S. Politics, (New York: W.W. Norton, 1996).

${ }^{46}$ C. Rasco, Summary, Comprehensive Childhood Immunization Act of 1993, Folder 6, Box 14, Domestic Policy Council, Rasco Subject File, William J. Clinton Presidential Library.

${ }^{47}$ W. J. Clinton, Statement of the President, Arlington County Department of Human Services, 2/12/93, Folder 7, Box 14, Domestic Policy Council, Rasco Subject File, William J. Clinton Presidential Library.

${ }^{48}$ R. Pear, "Clinton Considers Plan to Vaccinate All U.S. Children," New York Times, 1 February 1993 , A1. 
thinking, equating a child's right to vaccination with the commonly accepted rights of children to clean air, clean water, and public education. ${ }^{49}$

But vaccination was not just about rights for the administration, which also saw it as a means of reining in runaway health care costs. In addition to a broken health care system, Clinton had inherited a ruined economy, and he saw the two as tightly linked. In the spring of 1993, his administration promoted vaccines for children as an important way to save health care dollars. "Each day we delay really making a commitment to our children carries a dear cost," Clinton said before a joint session of Congress. 50 "We now know that we will save $\$ 10$ later for every $\$ 1$ we spend by eliminating childhood diseases. That's a good investment no matter how you measure it."

Pharmaceutical companies stringently opposed the Clinton plan, arguing that it would make vaccines unprofitable and bring the development of new vaccines to a halt. ${ }^{52}$ To an extent, many in Congress agreed. The vaccine proposal that ultimately passed as part of the 1993 budget act replaced universal purchase with a $\$ 300$ million plan to provide immunizations to Native American children, those on Medicaid, and those who lacked insurance coverage or coverage for vaccines. The new Vaccines for Children program provided states with added funds for vaccination and guaranteed their ability to purchase vaccines at federal contract prices, making low-cost vaccines available to children in both public clinics and private practices. ${ }^{53}$ That same spring, Clinton signed a proclamation supporting National Preschool Immunization Week, an annual week of coordinated efforts to fully vaccinate preschoolers with all federally recommended vaccines - including the vaccine against hepatitis B. ${ }^{54}$

The enactment of the Vaccines for Children program coincided with a broadened set of hepatitis B vaccine recommendations by the ACIP, which now urged that all 11- and 12 -year-olds be vaccinated against the virus. The committee stressed that universal infant vaccination should continue, but that adolescent vaccination was needed to cause disease incidence to decline more quickly. Health officials were blunt in justifying the widespread vaccination of youth. Vaccinating high-risk adults had proved enormously difficult, an ACIP statement noted, but routine childhood vaccination would obviate vaccination of adults. "W5 "We do not feel that targeting adults for vaccination has worked," a CDC official told the Boston Globe. "This will be the first time," she went on, "that a vaccine is recommended for children to prevent a disease that primarily occurs in adults."

As state health boards and legislatures began taking steps to mandate the hepatitis B vaccine for infants, kindergartners, and 7th graders, many directly attributed these steps to the new federal program. Minnesota's vaccine task force credited the Clinton changes for the extra funds and discount pricing that made it feasible to require the hepatitis B vaccine

\footnotetext{
${ }^{49}$ R. Pear, "Clinton, in Compromise, Will Cut Parts of Childhood Vaccine Plan," New York Times, 5 May 1993, A1.

${ }^{50}$ W.J. Clinton, Address before a Joint Session of Congress on Administration Goals, February 17, 1993

(The American Presidency Project, University of California, Santa Barbara).

51 Ibid.

52 J. Cohen, “Childhood Vaccines: The R\&D Factor," Science 259 (1993): 1528.

${ }^{53}$ G. Freed and S. Katz, "The Comprehensive Childhood Immunization Act of 1993: Toward a More Rational Approach," New England Journal of Medicine 329; 26 (1993): 1957.

${ }^{54}$ W.J. Clinton, Remarks by the President at Reading of Immunization Proclamation, Office of the Press Secretary, 4/12/93, William J. Clinton Presidential Library. (Available at http:/www.clintonlibrary.gov/ archivesearch.html)

${ }^{55}$ Centers for Disease Control, "Hepatitis B Virus: A Comprehensive Strategy for Eliminating Transmission in the United States through Universal Childhood Vaccination: Recommendations of the Immunization Practices Advisory Committee (ACIP)."

${ }^{56}$ D. Kong, "U.S. To Urge All Children Be Vaccinated for Hepatitis B,” Boston Globe, 11 June 1991.
} 
for 7 th graders. ${ }^{57}$ State health officials in Colorado, Louisiana, Pennsylvania, and elsewhere also credited the administration for making it possible to require the new vaccine for students, hold school-based drives to encourage vaccination, and enforce new mandatessince all students were now guaranteed vaccine, regardless of their ability to pay. ${ }^{58}$

At the same time, the rhetoric that once tightly linked hepatitis B to AIDS was beginning to diminish. A 1994 educational campaign by the National Foundation for Infectious Disease featured Dr. Ruth, who continued to inform audiences that hepatitis B was " 100 times more infectious than HIV."59 But when states like Idaho, California, and Pennsylvania mandated the vaccine in the following years, health officials and legislators cited not the opportunity to prevent an HIV-like scourge but, instead, the growing popularity of tattoos and body piercing, and the increased presence of diabetic syringes in schools, as justification. ${ }^{60}$ And although characterizations of hepatitis B as a sexuallytransmitted disease persisted, they increasingly gave way to characterizations of the virus as a preventable infection linked to cancer. "This is a very safe and effective way to avoid what is a terrible disease that causes cancer and other chronic problems," said the head of Colorado's health board on that state's decision to mandate the vaccine for school. ${ }^{61}$

\section{Vaccination resistance emerges}

The majority of state laws mandating hepatitis B vaccination for children thus went into effect between 1994 and 1998, taking advantage of federal enthusiasm for universal vaccination and funding support for recommended vaccines. When these laws were first introduced, members of the public with a lay understanding of hepatitis B most likely viewed it as an illness comparable to AIDS, if not in some ways worse - and yet preventable with a safe, new, cutting edge vaccine. But as hepatitis B vaccine laws became the norm, a debate over the merits of the shot began to simmer.

The debate that began to emerge in the late 1990s over the safety and appropriateness of the hepatitis B vaccine for children fit into a larger series of debates over vaccine safety that spanned the entire twentieth century and accelerated toward its end. In 1982, when a media exposé publicized a scientific dispute over the safety of pertussis vaccine, ${ }^{62}$ it galvanized a previously diffuse set of vaccine-anxious parents to lobby for new vaccine policies. The resulting 1986 National Vaccine Injury Compensation Act provided compensation for the families of vaccine-injured children and established the Vaccine Adverse Events Reporting System (VAERS), which began tracking reports of vaccinerelated harms in $1990 .^{63}$ By 1999, 42 states had mandated the hepatitis B vaccine for

\footnotetext{
${ }^{57}$ T. Majeski, "State Endorses Hepatitis Shots-Minnesota Is First to Recommend Immunizations for All Adolescents," St. Paul Pioneer Press, 6 November 1993, 1 A.

${ }^{58}$ P. Shinkle, "Vaccination Line Long as School Opening Nears," The Advocate (Baton Rouge, La.), 19 August 1993, 1A; Reuters, "Hepatitis B Vaccine for Babies Urged; Most of the Affected Americans Are First Infected as Young Adults," Philadelphia Inquirer, 18 October 1995, A12.

59 D. Eicher, "Hepatitis B Vaccine Carries a Quandary; Debate Rages over Necessity of Wide Usage," Denver Post, 27 June 1994.

${ }^{60}$ See for example A. Vogt, "Cda Schools First in Idaho to Offer Hepatitis B Shots," Idaho SpokesmanReview, 7 October 1997, A1; T. Nguyen, "Parents Need to Get Started on Schools' Hepatitis B Mandate," Los Angeles Times, 26 December 1998, 1.

${ }^{61}$ M. Romano, "Colorado Will Add Hepatitis B to Required Inoculations for Schoolchildren," Rocky Mountain News, 20 April 1996.

${ }^{62}$ L. Thompson, "DPT: Vaccine Roulette,” NBC News, April 19, 1982.

63 J.K. Colgrove, State of Immunity: The Politics of Vaccination in Twentieth-Century America (Berkeley: University of California Press, 2006)
} 
students, and over 25,000 reports of adverse events linked to the vaccine had been reported to VAERS. Scientists asserted that the mere number of events was far from proof of causation of harm, but parents insisted the figures revealed a different truth.

In the subsequent wave of reporting on hepatitis B, media reports focused on the perspective of patients, not scientists. In 1998, the media reported on France's decision to halt hepatitis B vaccination because of fears the shot caused neurological damage. ${ }^{64}$ Early in 1999, the television news program 20/20 aired a report on adults with impairments thought to be linked to the vaccine and an infant who died shortly after receiving the vaccine ${ }^{65}$ In the spring of 1999 , a House Committee held hearings on hepatitis B vaccine safety concerns. The hearings attempted to weigh the potential risks of the vaccine against the risks of what appeared, by this time, to be two very different diseases. To officials from the $\mathrm{CDC}$ and members of the American Liver Foundation and Hepatitis Foundation, hepatitis B was, primarily, a lethal disease that infected one in 20 Americans and caused 5,000 deaths each year, many of these from liver cancer. To members of Massachusetts Citizens for Vaccination Choice and Parents Requesting Open Vaccination Education, and to the doctors and parents who had witnessed blindness, deafness, seizures, and other effects in children following vaccination, hepatitis B was instead a rare, sexuallytransmitted infection that threatened drug addicts and foreigners and that posed no risk to American infants from healthy families. ${ }^{66}$

\section{Conclusion}

When New Jersey attempted to mandate the hepatitis B vaccine for its schoolchildren later that same year, some parents and a lone legislator resisted, citing reports of hazards and the inappropriateness of the vaccine for youth. ${ }^{67} \mathrm{New}$ Jersey's mandate easily passed, but in the years that followed, anti-vaccine and vaccine safety groups grew increasingly active. They were especially galvanized by news of potentially harmful levels of mercury in vaccines, the withdrawal of a new vaccine against rotavirus from the market because of safety concerns, and a now notorious study that purported to link the MMR vaccine to autism. As anti-vaccination sentiment swelled in the 2000 s, the hepatitis B vaccine was often held by critics as proof that policies were not always devised in the best interest of children. Critics looked to early scientific representations of hepatitis B as a sexually-transmitted disease affecting specific strata of the adult population as evidence in support of their position. "You pop out of the womb and the first thing you get is a shot for a sexuallytransmitted disease," one frustrated father told USA Today in 1999. ${ }^{68}$ The argument provided traction for vaccine critics over the course of the ensuing decade, a decade in which popular vaccination resistance grew. "Do we really need hepatitis B on the second day of life?" implored actor and vaccine critic Jim Carey on CNN's Larry King Live in

\footnotetext{
${ }^{64}$ Agence France-Presse, "France Ends Program of Hepatitis B Shots," New York Times, 3 October 1998, A4.

${ }^{65}$ ABC News, “20/20: Who's Calling the Shots?” January 22, 1999.

${ }^{66}$ Committee on Government Reform, Subcommittee on Criminal Justice, Drug Policy, and Human Resources, "Hepatitis B Vaccine: Helping or Hurting Public Health?", 106th Congress, 1st session, May 18 1999.

${ }^{67}$ L. Suhay, “A Skirmish over the Hepatitis B Vaccination,” New York Times, 18 July 1999, NJ1.

68 A. Manning, "Now Parents Fear Shots; Kids in USA Get 21 Shots before Start of 1st Grade," USA Today, 3 August 1999, 1A.
} 
2009. "The vaccine program is unbalanced," he said. "It's a good thing that's gone too far." 69

Recent opposition to the hepatitis B vaccine is, of course, just one episode in the long history of alternate acceptance and rejection of vaccination. In the early days of AIDS, hepatitis B was portrayed as a related infection urgently worth preventing; this association helped place the virus on par with such dreaded but also vaccine-preventable diseases as polio and smallpox, guaranteeing its position in the arsenal of childhood vaccines. But as AIDS became a pharmaceutically-manageable infection, and as parental concerns turned increasingly toward the rising prevalence of autism and other neurological conditions, the perceived risks of hepatitis B infection became overshadowed, for many, by the perceived risks of vaccination. The pattern is a familiar one in the history of vaccination resistance; historians James Colgrove and Dorothy Porter have both described a similar trend in public attitudes toward the polio vaccine as prevalence of that disease diminished. ${ }^{70}$ Progressive Era anti-vaccinationists, described by historian Robert Johnston, likewise came to perceive the vaccine against smallpox as riskier than a chance with the disease itself. $^{71}$

Before hepatitis B vaccine became the target of vaccination resistors, however, it was, at least briefly, accepted widely as an addition to the spectrum of vaccines for children. The factors key to securing the vaccine's acceptance are revealed by an examination of the constant evolution of the image of hepatitis B infection before the eyes of lay Americans. The hepatitis B vaccine's disease target, as this analysis has shown, was framed very differently in the shot's first decade of existence than it was in subsequent decades. Textual and visual representations of the disease in the 1970s and 1980s indicate that lay observers were initially given little reason to worry about hepatitis B infection or anxiously anticipate its vaccine. Over the course of the 1980s, however, the disease itself was no longer represented as the province of marginalized groups but rather as a deadly killer akin to AIDS - albeit preventable with the fruits of the most cutting-edge scientific technology. The widespread adoption of hepatitis B vaccine laws that followed in the 1990s reflected the fears and hopes of a nation stricken by AIDS, briefly smitten with biotechnology, and hobbled by a broken health care system - all told, a set of preoccupations that were directly reflected in ever-evolving portrayals of hepatitis B itself. The vaccination of children, specifically, presented the most expedient means of addressing these fears, as the remarks of health officials, and the compliance of legislators and communities, reveals. The nation's hopes and fears would change shape again, in the late 1990s and early 2000s, and so too would perceptions of hepatitis B and its vaccine - but this would occur only after the vaccine was made mandatory for every child in the nation.

Open Access This article is distributed under the terms of the Creative Commons Attribution Noncommercial License which permits any noncommercial use, distribution, and reproduction in any medium, provided the original author(s) and source are credited.

\footnotetext{
${ }^{69}$ CNN, "Larry King Live: Jenny McCarthy and Jim Carrey,” April 2, 2009.

${ }^{70}$ D. Porter, "Tyranny or Salvation? Historical Perspectives on Vaccination," unpublished paper, 1988.

${ }^{71}$ R. Johnston, The Radical Middle Class: Populist Democracy and the Question of Capitalism in Progressive Era Portland, Oregon (Princeton: Princeton University Press, 2003).
} 